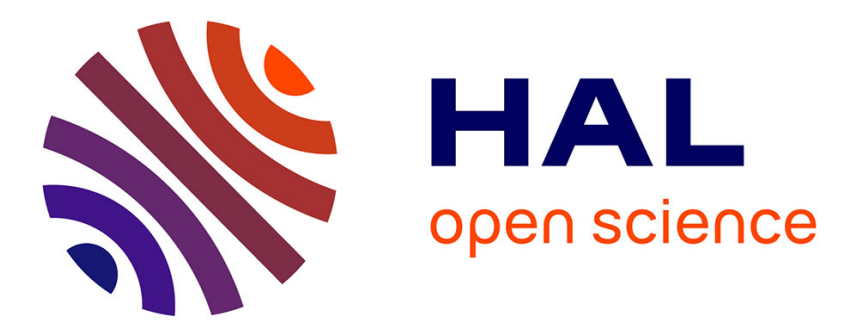

\title{
Rate coefficients for the reaction of ozone with 2- and 3-carene
}

H Chen, Y Ren, M. Cazanau, Véronique Daële, Y. Hu, Jie Chen, Abdelwahid S Mellouki

\section{> To cite this version:}

H Chen, Y Ren, M. Cazanau, Véronique Daële, Y. Hu, et al.. Rate coefficients for the reaction of ozone with 2- and 3-carene. Chemical Physics Letters, 2015, 621, pp.71-77. 10.1016/j.cplett.2014.12.056 . insu-01103130

\section{HAL Id: insu-01103130 https://hal-insu.archives-ouvertes.fr/insu-01103130}

Submitted on 15 Jan 2015

HAL is a multi-disciplinary open access archive for the deposit and dissemination of scientific research documents, whether they are published or not. The documents may come from teaching and research institutions in France or abroad, or from public or private research centers.
L'archive ouverte pluridisciplinaire HAL, est destinée au dépôt et à la diffusion de documents scientifiques de niveau recherche, publiés ou non, émanant des établissements d'enseignement et de recherche français ou étrangers, des laboratoires publics ou privés. 


\title{
Rate coefficients for the reaction of ozone with 2- and 3-carene
}

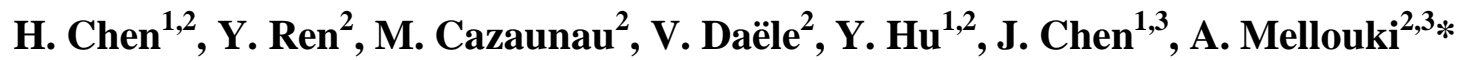

${ }^{1}$ Shanghai Key Laboratory of Atmospheric Particle Pollution and Prevention (LAP ${ }^{3}$ ), Department of Environmental Science \& Engineering, Fudan University, Shanghai 200433, China

${ }^{2}$ Institut de Combustion, Aérothermique, Réactivité et Environnement/OSUC, CNRS, 45071 Orléans cedex 02, France

${ }^{3}$ School of Environmental Science \& Engineering, Shandong University, Shandong 250100, China

* Corresponding author:

A. Mellouki, ICARE-CNRS, 1C Avenue de la Recherche Scientifique, 45071 Orléans Cedex 02, France (Fax: (33) 238 696004, e-mail: mellouki@cnrs-orleans.fr) 


\begin{abstract}
:
The rate coefficients for the reactions of ozone with 2-carene and 3-carene have been measured at 760 torr of air and $299 \pm 6 \mathrm{~K}$ using both absolute and relative methods. The data obtained are (in units of $\times 10^{-17} \mathrm{~cm}^{3}$ molecule $\left.\mathrm{s}^{-1}\right): k(2$-carene $)=23.8 \pm 1.0, k(3$-carene $)=3.7 \pm 0.2$. The present work supplements the kinetic database of 2-carene and 3-carene using varied conventional experimental methods. The results are compared with the literature data and discussed with respect to atmospheric chemistry.
\end{abstract}

Keywords: Ozone, 2-carene, 3-carene, rate coefficients 


\section{INTRODUCTION}

It is well recognized that a wide variety of biogenic volatile organic compounds (BVOCs) are emitted into the atmosphere from terrestrial vegetation [1]. Isoprene and monoterpenes are the dominant on a global scale [2]. Once emitted, these BVOCs undergo chemical oxidation through reactions with ozone, $\mathrm{OH}$ and $\mathrm{NO}_{3}$ radicals. The existing literature data shows that $\mathrm{OH}$ and $\mathrm{NO}_{3}$ radicals reactions constitute important atmospheric removal processes of the unsaturated BVOCs during the day and night, respectively $[3,4]$, while the reaction with $\mathrm{O}_{3}$ could be important both during the day and night [5]. Moreover, ozonolysis of BVOCs is important with respect to production of $\mathrm{HO}_{\mathrm{X}}\left(\mathrm{OH}\right.$ and $\left.\mathrm{HO}_{2}\right)$ and $\mathrm{RO}_{2}$ radicals in remote areas and for secondary organic aerosol (SOA) formation [5,6]. The evaluation of the contribution of the ozonolysis as a potential degradation process for BVOCs requires reliable kinetic data in order to evaluate their fate and contribution in the global atmospheric chemistry.

The rate coefficients values for the reaction of $\mathrm{O}_{3}$ with alkenes depend on the number and identity of alkyl substituents that have both inductive and steric effects. McGillen et al. have developed a structure-activity relationship (SAR) that has been found to perform well for a wide range of open chain alkenes and conjugated dienes [7]. The method was highly parameterized but is not recommended for endocyclic alkenes. The other effects such as ring strain, the asymmetry degree, and conformational constraints have to be taken into account. Hence, experimental data are needed for variety of unsaturated BVOCs in order to improve the existing SAR to enhance the capabilities of the predictive methods to estimate the rate coefficient values for the reactions of ozone with complex organic species. 
In the present work, we have measured the rate coefficients for the reaction of $\mathrm{O}_{3}$ with 2-carene (3,7,7-trimethyl-bicyclo[4.1.0]hept-2-ene) and 3-carene (3,7,7-trimethyl-bicyclo[4.1.0]hept-3ene):

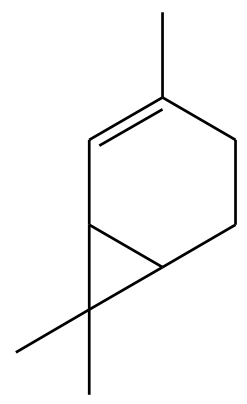

2-Carene

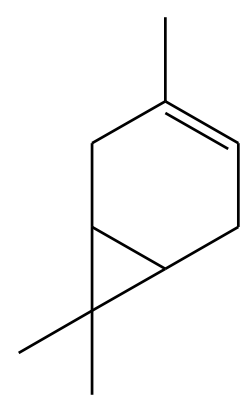

3-Carene

2- and 3-carene are two important BVOC species characterized with an $\alpha$-methyl-substituted endocyclic olefinic bond. The absolute and relative rate coefficients have been measured in three complementary experimental systems: two atmospheric simulation chambers and a laminar flow reactor. The kinetic measurements of 2- and 3-carene have been performed previously only a few times, most of which were conducted decades ago. The kinetic data obtained in this work are compared with the previous studies and discussed in terms of the atmospheric implications.

\section{EXPERIMENTAL}

\subsection{Reactors}

Three complementary experimental systems have been used during this work:

7300 L simulation chamber (SC): Absolute and relative rate coefficients were measured using the ICARE-7300 L Teflon chamber [8]. Experiments were performed in Pressure 760 torr of air at Temperature $=295 \pm 1 \mathrm{~K}$ with a relative humidity of $\sim 5 \%$. Reagents that are liquids under ambient conditions were introduced into the chamber by placing a known volume in a glass-made 
bubbler which was then flushed by purified air (gently heated when necessary). The concentration of carene was monitored by a commercial Proton-Transfer-Reaction Time-ofFlight (PTR-TOF, Ionicon). Ozone was produced using a silent discharge in $\mathrm{O}_{2}$ and its concentration was measured by UV absorption (Horiba, APOA-360). Two fans installed into the chamber ensured rapid mixing of reactants. Temperature and relative humidity data were continuously recorded by a combined sensor placed in the chamber. To prevent contamination from outside air, a flow of purified air was added continuously during all experiments to keep the chamber slightly above atmospheric pressure and to compensate for sampling flows of various instruments connected to the chamber.

90000 L simulation chamber (HELIOS): newly constructed at ICARE-CNRS, made from teflon and in the shape of truncated hemisphere with a surface to volume ratio of $1.2 \mathrm{~m}^{-1}$. Absolute rates were measured in excess of ozone over carene. Experiments were performed in Pressure $\sim 743-754$ torr of air at Temperature $=293-305 \mathrm{~K}$ with a relative humidity of $\sim 0.4 \%$ (dew point $=-45^{\circ} \mathrm{C},\left[\mathrm{H}_{2} \mathrm{O}\right] \sim 2.5 \times 10^{15}$ molecule $\mathrm{cm}^{-3}$ ). The operation procedures, including VOCs and $\mathrm{O}_{3}$ injection, flow compensation, etc., are similar to those in $7300 \mathrm{~L}$ simulation chamber. While ozone was monitored by either APOA-360 or in-situ Fourier transform infrared spectrometer (FTIR, Vertex 70, Bruker, optical length $=302.6 \mathrm{~m}$ ), carene was monitored by PTR-TOF. Two fans installed into the chamber ensured rapid mixing of reactants.

Laminar flow reactor: The laminar flow reactor has been described in details previously [9]. Briefly, the flow reactor consists of a vertical 100-cm-long Pyrex glass tube with $10 \mathrm{~cm}$ i.d. and a 110-cm-long movable mixing plunger with $1.2 \mathrm{~cm}$ i.d.. With the $2.8 \mathrm{~L} \mathrm{~min}^{-1}$ "ozone flow" through the injector and the $1.8 \mathrm{~L} \mathrm{~min}^{-1}$ "carene flow" through the reactor tube, the reaction time was varied in the range of 17-55 s by adjusting the position of the mixing plunger relatively to the 
sampling point at the bottom of the reactor $(30-90 \mathrm{~cm})$. In our experimental conditions with the total flow rate of $4.6 \mathrm{~L} \mathrm{~min}^{-1}$ (the flow velocity, $\mathrm{Ve} \sim 1.57 \mathrm{~cm} \mathrm{~s}^{-1}$ ), the flow reactor was characterized by a Reynolds number of $\sim 107$ and a Knudsen number of $6.6 \times 10^{-17}$, corresponding to a laminar and viscous flow. Experiments were performed at $\mathrm{T}=296 \pm 1 \mathrm{~K}, \mathrm{P}=$ $760 \pm 0.5$ Torr and relative humidity $\leq 1 \%$. Ozone was produced by passing the controlled mixture of synthetic air and nitrogen through a UV Pen-ray lamp. Its concentration was measured at the outlet of the reactor by an UV absorption ozone monitor (France Environment 41M; Horiba APOA-360). Carene was premixed with nitrogen (typically $\sim 0.05 \%$ ) in a $10 \mathrm{~L}$ glass bulb at a total pressure of 800-1000 Torr. The flow from the bulb was controlled by a calibrated mass flow controller to determine the carene concentration in the flow reactor. Additional calibration was conducted for the glass bulbs by means of dynamic dilution which agreed with the calibration conducted in the simulation chamber within $\sim 5 \%$ uncertainty. Since the carene concentrations were not measured directly during experiments, an uncertainty of $10 \%$ was used for data evaluation.

\subsection{Instruments}

PTR-TOF: PTR-TOF was running under E/N $137 \mathrm{Td}\left(10^{-7} \mathrm{~V} \mathrm{~cm}^{2} \mathrm{molecule}^{-1}\right.$, i.e., drift pressure of 2.1 mbar and voltage of $600 \mathrm{~V}$ ). The mass resolution typically ranged from 3500 to 4500 $\mathrm{m} / \Delta \mathrm{m}$. The sensitivities for measurement of 2-carene, 3-carene and cyclohexene were 8.8 and $11.5(\mathrm{~m} / \mathrm{z} 81$ and m/z 137), 9.8 and $7.8(\mathrm{~m} / \mathrm{z} 81$ and m/z 137) and $4.3(\mathrm{~m} / \mathrm{z} \mathrm{83)}$ (in units of ncps/ppbv), respectively. The detection limit ( $3 \sigma$ of the zero noise) was $\sim 50 \mathrm{pptv}$ for carenes and cyclohexene. The measurement precision was estimated as $\Gamma \sim 5 \%$ obtained from $1 \sigma$ uncertainty of the calibration. 
Multipath FTIR: It consists of Bruker Vertex 70 FTIR spectrometer equipped with DigiTect high sensitivity detector DLATGS (D301/B) system and coupled to a white-type mirror system in the chamber resulting of an optical path of 302.6 meters. The reactants and products were monitored in the spectral range $8.000-350 \mathrm{~cm}^{-1}$. Samples were averaged from 250 scans which typically took 3 minutes. The concentration of ozone was quantified by comparison with reference ozone spectra at the wavelength range $900-1070 \mathrm{~cm}^{-1}$.

\subsection{Kinetic measurements}

The rate coefficients for the reaction of $\mathrm{O}_{3}$ with 2- and 3-carene were determined by the absolute and relative methods using the three reactors described above.

Absolute method: Experiments were carried out under pseudo-first-order conditions with $[\text { carene }]_{0} \gg\left[\mathrm{O}_{3}\right]_{0}$ or conversely. In the case of carene in excess (performed in SC and in the flow reactor), the temporal profiles of $\left[\mathrm{O}_{3}\right]$ is given by:

$$
\begin{gathered}
{\left[\mathrm{O}_{3}\right]_{t}=\left[\mathrm{O}_{3}\right]_{0} e^{-k^{\prime} t}} \\
\ln \left(\frac{\left[\mathrm{O}_{3}\right]_{0}}{\left[\mathrm{O}_{3}\right]_{t}}\right)=k^{\prime} t \quad \text { or } \ln \left(\left[\mathrm{O}_{3}\right]_{t}\right)=-k^{\prime} t+\ln \left(\left[\mathrm{O}_{3}\right]_{0}\right) \\
\text { where } k^{\prime}=f([\text { carene }])=k_{i}[\text { carene }]+k_{0, \mathrm{O}_{3}}^{\prime}
\end{gathered}
$$

where $k_{i}$ represents the rate coefficients for the reaction of ozone with 2- and 3-carene, as a

function of the concentration of carene $(f([$ carene $]))$, and $k_{0 \text {,carene }}^{\prime}$ is the first-order ozone decay 
rate in the absence of carene. $k_{i}$, the bimolecular rate coefficient for the ozonolysis of carene, is obtained from the slope of the plot $k^{\prime}-k_{0, \text { carene }}^{\prime}$ vs. [carene].

In the case of $\mathrm{O}_{3}$ in excess (performed in HELIOS), one species among cyclohexane, 1,3,5trimethylbenzene (TMB) and 2-butanol was employed to scavenge $\mathrm{OH}$ radicals produced by reactions of $\mathrm{O}_{3}$ with carene. The rate coefficients $\left(k_{i}\right)$ are derived from the Eq. (4):

$$
k^{\prime}=f\left(\left[\mathrm{O}_{3}\right]\right)=k_{i}\left[\mathrm{O}_{3}\right]+k_{0, \text { carene }}^{\prime}
$$

where $k^{\prime}$ and $k_{0,0_{3}}^{\prime}$ are the decay rates of carenes in the presence or absence of ozone, respectively. $k_{i}$, as a function of the concentration of ozone $\left(f\left(\left[\mathrm{O}_{3}\right]\right)\right)$, is obtained from the slope of the plot $k^{\prime}-k_{0, \mathrm{O}_{3}}^{\prime}$ vs. $\left[\mathrm{O}_{3}\right]$. The decay of 2- and 3-carene and cyclohexene were monitored by PTR-TOF.

Relative method: Experiments were performed both in SC and in HELIOS. Relative rate coefficients for the reactions of ozone with 2- and 3-carene were determined by comparing their rates of decay with that of a reference compound (cyclohexene in the present work) whose reaction rate coefficients $\left(k_{r e f}\right)$ is well established.

$$
\ln \left(\frac{[\text { carene }]_{0}}{[\text { carene }]_{t}}\right)-k_{0, \text { carene }}^{\prime} \times t=\frac{k_{i}}{k_{\text {ref }}} \times\left[\ln \left(\frac{[\text { cyclohexene }]_{0}}{[\text { cyclohexene }]_{t}}\right)-k_{0, \text { cyclohexene }}^{\prime} \times t\right]
$$

where $k_{0}^{\prime}$ is the first-order decay rate of carene or cyclohexene in the absence of ozone and $t$ is the reaction time. Since ozonolysis of carene generates $\mathrm{OH}$ radicals that may lead to much faster decay of the reactants, $\mathrm{OH}$ scavenger was injected simultaneously to scavenge more than $90 \%$ of $[\mathrm{OH}]$. 
Note that in some experiments (i.e. 3CAR-6BR and 2CAR-5BR), excess ozone was injected in one addition, in which case that absolute and relative rates were simultaneously derived from the data sets.

\section{RESULTS}

\subsection{Absolute rate measurements}

For experiments performed in the flow reactor and in $\mathrm{SC}$, the initial concentrations of carene and ozone were in the range of $0.9-12.1 \times 10^{13}$ and $1.0-3.0 \times 10^{12}$ molecule $\mathrm{cm}^{-3}$, respectively. The use of large excess of carene over ozone enables to make secondary ozone reactions such as ozone with $\mathrm{OH}$ and $\mathrm{HO}_{2}$ radicals negligible $\left(k\left(\mathrm{OH}+\mathrm{O}_{3}\right)=7.3 \times 10^{-14} ; k\left(\mathrm{HO}_{2}+\mathrm{O}_{3}\right)=2.0 \times 10^{-15} \mathrm{~cm}^{3}\right.$ molecule $\left.\mathrm{s}^{-1}[10]\right)$. The experimental conditions and the results obtained are summarized in Table 1. Typical data sets of pseudo first order rate coefficients are plotted in Figure 1. $k^{\prime}-k_{0, \text { carene }}^{\prime}$ derived from experimental data from both the flow reactor and simulation chamber are plotted against the concentration of carene in Figure 2a to obtain the absolute rate coefficients, $k_{i}$. It is worth noting that significant uncertainties for the pseudo first order rate coefficients measured at low concentration in the flow reactor was caused by the comparable $k_{0}^{\prime}$. The rate coefficients are determined (in units of $10^{-17} \mathrm{~cm}^{3}$ molecule $\left.\mathrm{s}^{-1}\right): \mathrm{k}\left(\mathrm{O}_{3}+3\right.$-carene) $=4.9 \pm 0.8$ (flow reactor), $=3.5 \pm 0.2(\mathrm{SC}) ; \mathrm{k}\left(\mathrm{O}_{3}+2\right.$-carene $)=24.7 \pm 2.5$ (flow reactor) .

$41 \mathrm{M}$ or APOA-360 ozone monitors were respectively utilized for 2-carene and 3-carene experiments in the flow reactor since they showed no interference with corresponding carene in the absence of ozone. However, negative readings were observed at the end of reactions on $41 \mathrm{M}$ or APOA-360 ozone monitors respectively for 2- and 3-carene experiments performed in SC (Suppl. Fig. 2). In the case of 3-carene, the negative readings (up to "-19" ppbv) showed 
significant correlation with the concentration of consumed ozone (i.e. consumed 3-carene), inferring that the products of reaction between ozone and 3-carene in the absence of $\mathrm{OH}$ scavenger caused the interference. Thereby, the ozone concentration profiles have been corrected from the "negative" contribution from the products that related to the consumption of ozone. Note that the interference was expected to be minor in the flow reactor since the reaction was limited by residence time for a maximum of $55 \mathrm{~s}$. However, a possible overestimation of pseudo first order rate coefficients due to the negative interferences cannot be excluded.

The first order rate coefficients of ozone loss in the absence of any organic reagents were typically $(8 \pm 4) \times 10^{-4} \mathrm{~s}^{-1}$ and $(2.0 \pm 0.9) \times 10^{-5} \mathrm{~s}^{-1}$ for the flow reactor and SC, respectively. The pseudo first order rate coefficients derived from the decay of ozone in the presence or 2- and 3carene carried out in the flow reactor might be subject to diffusion processes. The diffusion coefficient in air $\left(D_{O 3-A i r}\right)$ was estimated to be $0.164 \mathrm{~cm}^{2} \mathrm{~s}^{-1}$ at $293 \mathrm{~K}$ [11]. The plug-flow approximation where

$$
\frac{k_{\text {Meas }}^{\prime} \times R^{2}}{D_{O_{3}-\text { Air }}} \leq 1.5
$$

with $k_{\text {Meas }}^{\prime}$ is the measured pseudo first order rate coefficient $\left(\right.$ in $\left.^{-1}\right), R$ is the inner radius of the flow reactor (in $\mathrm{cm}$ ) and $D_{O 3-A i r}$ is the diffusion coefficient of ozone in air $\left(\right.$ in $\mathrm{cm}^{2} \mathrm{~s}^{-1}$ ) can be applied to the experimental system for $k_{\text {Meas }}^{\prime} \leq 9.84 \times 10^{-3} \mathrm{~s}^{-1}$ and the concentration of ozone was homogeneous all over the flow section. For $k_{\text {Meas }}^{\prime} \geq 9.84 \times 10^{-3} \mathrm{~s}^{-1}$, the measured pseudo first order rates have been corrected for radial diffusion using the formula: $k^{\prime}=k^{\prime}{ }_{\text {Meas }} \times\left(1+D_{\text {eff }} \times k_{\text {Meas }}{ }_{\text {Mea }} / V e^{2}\right)$ with $D_{\text {eff }}=D_{O_{3}-A i r}+R^{2} \times V e^{2} /\left(48 \times D_{O_{3}-A i r}\right)$ where $D_{\text {eff }}$ is the effective diffusion coefficient, preferred to $D_{O 3-A i r}$. The correction factor applied to $k_{\text {Meas }}$ in the present work ranged from 1.04 
to 1.12 . Furthermore, the value $k_{\text {Meas }}^{\prime} \times D_{O_{3}-\text { Air }} / V e^{2}$ was found to be $2.5 \times 10^{-3} \ll 1\left(k_{\text {Meas, max }}^{\prime}=\right.$ $3.79 \times 10^{-2} \mathrm{~s}^{-1}$ ) which indicated that axial diffusion can be considered negligible in our experimental conditions and therefore, $k_{\text {Meas }}^{\prime}$ has not been corrected [9].

For experiments performed in HELIOS, the initial concentrations of carene were in the range of 1.6-6.9 $\times 10^{11}$ molecule $\mathrm{cm}^{-3}$, while the concentrations of ozone were typically $2.4-10.0 \times 10^{12}$ molecule $\mathrm{cm}^{-3}$ (Table 2 \& Suppl. Table 1).

To make sure that carene was removed solely by reaction with ozone, experiments were carried out, in the presence of sufficient concentrations of cyclohexane, TMB or 2-butanol to scavenge most of the $\mathrm{OH}$ radicals produced from the ozonolysis of carene, i.e.,

$$
\frac{k_{\mathrm{OH}+\mathrm{Scav}} \times[\mathrm{Scav}]_{0}}{k_{\mathrm{OH}+\text { carene }} \times[\text { carene }]_{0}}>10
$$

The parent peak of m/z 137.13 was usually used for calculating the concentration of carene, while the fragment peak of m/z 81.07 was used when available (Fig. 2b and Table 2). Cyclohexane, 2butanol or TMB have been used as $\mathrm{OH}$ scavengers (Suppl. Table 1). Since TMB reacts with $\mathrm{OH}$ at a rate comparable to that of carene, relatively low concentration of TMB compared to that of 2butanol and cyclohexane was added to the chemical system to scavenge $\mathrm{OH}$. However, several "products" peaks were observed on PTR-TOF spectra when $\mathrm{O}_{3}$ and TMB were present in HELIOS, which might originate from some side reaction occurring in the drift tube or other phenomena. Among those peaks, significant isobaric peak of m/z $137.10\left(\mathrm{C}_{9} \mathrm{H}_{13} \mathrm{O}^{+}\right)$can affect the evaluation of carene decay using m/z 137.13 (Suppl. Fig. 3). Taking advantage of the high-massresolution feature of PTR-TOF, the concentration of carene (m/z 137.13) was obtained using 
appropriate multi-peak separation method. Its decay rate showed no difference from that of fragment peak at m/z 81.07 (Fig. 2b).

Cyclohexane was preferred for PTR-TOF measurement because its proton affinity is lower than that of water molecule, which makes it undetectable. There was only $k$ ' available derived from $\mathrm{m} / \mathrm{z} 137.13$ because cyclohexanone, a product of reaction between cyclohexane and $\mathrm{OH}$, shared the fragment peak of $\mathrm{m} / \mathrm{z} 81.07$ with carene. Similarly, the $k^{\prime}$ derived from the decay of $\mathrm{m} / \mathrm{z}$ 81.07 in the presence of cyclohexene as a reference has been excluded because interference from

cyclohexene at $\mathrm{m} / \mathrm{z} 81.07$ made them overestimated. Unsurprisingly, $k$, i.e. $k_{\mathrm{O}_{3}+\text { Carene }} \times\left[\mathrm{O}_{3}\right]$ showed great linearity with either TMB, 2-butanol or cyclohexane as a scavenger. Since we have no reason to decline the data sets derived either from $\mathrm{m} / \mathrm{z} 137.13$ or $\mathrm{m} / \mathrm{z} 81.07$, the $k$ was extracted from all data (in units of $10^{-17} \mathrm{~cm}^{3}$ molecule $\left.{ }^{-1} \mathrm{~s}^{-1}\right): \mathrm{k}\left(\mathrm{O}_{3}+3\right.$-carene $)=3.7 \pm 0.2 ; \mathrm{k}\left(\mathrm{O}_{3}+2\right.$ carene) $=23.9 \pm 1.3$

\subsection{Relative rate measurements}

The decay rates of 2- and 3-carene and cyclohexene in the absence of ozone were determined before initiating the reaction. The initial concentration of carene and cyclohexene were in the range of 580-4800 ppbv (SC) and 6.7-30 ppbv (HELIOS). Their decays were monitored by the PTR-TOF at a time resolution of 15 to $60 \mathrm{~s}$ at protonated $\mathrm{m} / \mathrm{z} 137.13$ and $\mathrm{m} / \mathrm{z} 83.09$. The $\mathrm{m} / \mathrm{z}$ 83.09 and $\mathrm{m} / \mathrm{z} 137.13$ were found to interfere with isobaric peaks of $\mathrm{m} / \mathrm{z} 83.05\left(\mathrm{C}_{5} \mathrm{H}_{7} \mathrm{O}^{+}\right)$and $\mathrm{m} / \mathrm{z}$ $137.10\left(\mathrm{C}_{9} \mathrm{H}_{13} \mathrm{O}^{+}\right)$, respectively (Suppl. Fig. 4). Those isobaric peaks might originate from the products of the reactions between carene/cyclohexene and ozone or their fragments. Manually Gauss peak fits (SC) or PTR-data analyzer (HELIOS) [12] were applied on the high-resolution (3000-4000 $\Delta \mathrm{m} / \mathrm{m}$ ) mass spectra to obtain the peak intensities of $\mathrm{m} / \mathrm{z} 137.13$ and $\mathrm{m} / \mathrm{z} 83.09$. 
Figure 3 shows examples of experimental plots derived from the analysis of a relative rate measurement for the reactions of ozone with 2- and 3-carene, respectively. As expected, straight lines with a zero intercept were obtained, showing in all cases a good linearity. The uncertainties on both abscissa and ordinate scales were derived from the measurement uncertainties $\left(\Gamma=\frac{\sigma}{[\text { carene }]}\right.$ or $\left.\frac{\sigma}{[\text { cyclohexene }]}=5 \%\right)$ and propagation for $\ln \left(\frac{[\text { carene }]_{0}}{[\text { carene }]_{t}}\right)$ or $\ln \left(\frac{[\text { cyclohexene }]_{0}}{[\text { cyclohexene }]_{t}}\right)$. For $f=\ln \left(\frac{[A]_{0}}{[A]_{t}}\right), \Gamma_{f}=\frac{\sigma_{f}}{f}=\sqrt{\frac{\sigma_{0}}{[A]_{0}}+\frac{\sigma_{t}}{[A]_{t}}}=\sqrt{2} \Gamma$ resulted in an uncertainty $\sim 7 \%$. The rate coefficients of the reactions of ozone with 2- and 3-carene obtained using the relative rate method, are summarized in Table 3. 91\%-95\% of $\mathrm{OH}$ radicals were scavenged during the experiments. The measured rate coefficients ratios were placed on an absolute basis using the $\mathrm{k}\left(\mathrm{O}_{3}+\right.$ cyclohexene $)=7.9 \times 10^{-17} \mathrm{~cm}^{3}$ molecule $\mathrm{s}^{-1}$ at $296 \mathrm{~K}[13,14]$. The final rate coefficients values were derived by averaging the data from different experiments with error limits that encompass the extremes of $\sigma$ error of the individual determinations and do not include systematic errors and uncertainties of the reference rate coefficients which could be as high as $25 \%$.

In addition, $k\left(\mathrm{O}_{3}+\right.$ cyclohexene $)$ was determined simultaneously during Exp. 3CAR-6BR and 2CAR-5BR (Table 4). The obtained rate coefficient of $(7.4 \pm 0.5) \times 10^{-17} \mathrm{~cm}^{3}$ molecule $\mathrm{s}^{-1}$ at 295 $\pm 2 \mathrm{~K}$ is in good agreement with literatures [14-16].

\section{DISCUSSION}

The rate coefficients obtained in the present work using three different facilities (the flow reactor, SC and HELIOS) are compared with the existing data in the literature in Table 5. Recommendations from IUPAC [10] are also included for comparison. $\mathrm{k}\left(\mathrm{O}_{3}+2\right.$-carene $)$ values 
measured with the absolute and relative rate methods in our laboratory are in good agreement with each other and with the only available experimental results from Atkinson, et al. [17] where both absolute and relative rate methods were used.

On the other hand, the rate coefficients for reaction of ozone with 3-carene obtained from the flow reactor is $\sim 30 \%$ higher than those using other methods. This would be partially explained by the interferences of $\mathrm{O}_{3}$ monitor. Additionally, limited by the vapor pressure of 3-carene, its concentration in the flow reactor could not exceed $11.3 \times 10^{13}$ molecule $\mathrm{cm}^{-3}$ under our experimental conditions. In this case, the $k^{\prime}$ was only $\sim 5.5$ times higher than the typical wall loss rate, which made the extracted slope of $k^{\prime}$ against [3-carene] of great uncertainties. The rate coefficients reported by Grimsrud, et al. [18] for a series of terpenes are higher than those of subsequent studies. In a more recent study from Atkinson, et al. [17], the presence of reactive impurities in the 3-carene sample used was reported (3\% sabinene and/or $\beta$-pinene and $2.9 \%$ limonene), such that the measured absolute rate by monitoring the decay rate of $\mathrm{O}_{3}$ in the presence of excess 3-carene was believed to be overestimated by up to about $20 \%$. In the present study, the stated purity of 3 -carene was $\geq 98.5 \%$ (more details in supplementary), and the impurities at this level would not significantly affect our absolute and relative rates. Witter, et al. [19] reported $k\left(\mathrm{O}_{3}+3\right.$-carene $)=5.6 \times 10^{-17} \mathrm{~cm}^{3}$ molecule $\mathrm{s}^{-1}$ using relative method in a flow reactor. It is $\sim 50 \%$ higher than the other values, for which the reason is unknown.

Eventually, we present updated rate coefficients values for reactions of ozone with 2- and 3carene by averaging the values reported in this study and from Atkinson, et al. [17]: $k\left(\mathrm{O}_{3}+2-\right.$ carene $)=23.9 \pm 1.0$ and $k\left(\mathrm{O}_{3}+3\right.$-carene $)=3.8 \pm 0.2\left(\right.$ in units of $\times 10^{-17} \mathrm{~cm}^{3}$ molecule $\left.\mathrm{s}^{-1}\right)$ at 296 $\pm 2 \mathrm{~K}$. For 3-carene, only the results derived from AM-SC, AM-HELIOS, RM-HELIOS in this study and RM in Atkinson, et al. [17] are used. 
In terms of the structure-activity relationships (SAR), 2- and 3-carene have a moiety as 2,2dimethyl-2-pentene. No kinetic data of 2,2-dimethyl-2-pentene was available for comparison to date, and it was expected to be in the range of that of 2-methyl-2-pentene $\left(43.0 \times 10^{-17} \mathrm{~cm}^{3}\right.$ molecule $\left.\mathrm{s}^{-1}\right)$ and 2,4,4-trimethyl-2-pentene $\left(13.2 \times 10^{-17} \mathrm{~cm}^{3}\right.$ molecule $\left.\mathrm{s}^{-1}\right)$ because of the variable steric effect dependent on the number of 4-methyl substitutes [20]. Therefore, with rate coefficient of $2.4 \times 10^{-16} \mathrm{~cm}^{3}$ molecule $\mathrm{s}^{-1}$, the bicyclic structure of 2-carene is empirically speculated to be strain-free and show no additional steric effect. On the other hand, 3-carene reacts much slower with ozone even compared with 2,4,4-trimethyl-2-pentene, inferring additional steric effects induced by its specific structures. The additional steric effects arise from mainly two hypothesis: (1) the conformational constraints of a C6-ring system containing two $\mathrm{sp}^{2}$ hybridized carbons could inhibit reaction with ozone; (2) the bridgehead carbon out of the plane of the six membered ring like $\alpha$-pinene and camphene cause additional steric effect [21].

\section{CONCLUSION}

2- and 3-Carene are expected to be removed from the troposphere through reactions with the main atmospheric oxidants $\left(\mathrm{OH}, \mathrm{NO}_{3}\right.$ and $\left.\mathrm{O}_{3}\right)$. The available kinetic data on the reactions of $\mathrm{OH}$ and $\mathrm{NO}_{3}$ and the ones determined in the present work on $\mathrm{O}_{3}$ enable to estimate the atmospheric lifetimes for 2 - and 3-carene. Using tropospheric $[\mathrm{OH}] \approx 2 \times 10^{6}$ molecule $\mathrm{cm}^{-3}$ (12-h average), $\left[\mathrm{NO}_{3}\right] \approx 2 \times 10^{8}$ molecule $\mathrm{cm}^{-3}\left(12\right.$-h average, [4]) and $\left[\mathrm{O}_{3}\right] \approx 10^{12}$ molecule $\mathrm{cm}^{-3}$ (24-h average) the tropospheric lifetimes $\left(\tau=1 / k[X]\right.$ with $\mathrm{X}=\mathrm{OH}, \mathrm{NO}_{3}$ and $\left.\mathrm{O}_{3}\right)$ with respect to reactions of carenes with $\mathrm{OH}\left(\mathrm{k}(2\right.$-carene $)=8 \times 10^{-11}$ and $\mathrm{k}(3$-carene $)=8.8 \times 10^{-11}$ in units of $\mathrm{cm}^{3}$ molecule $^{-1}$ $\left.\mathrm{s}^{-1}[13]\right), \mathrm{NO}_{3}\left(\mathrm{k}(2\right.$-carene $)=2 \times 10^{-11}$ and $\mathrm{k}(3$-carene $)=9.1 \times 10^{-12}$ in units of $\mathrm{cm}^{3}$ molecule $\mathrm{s}^{-1}$ [10] $)$ and $\mathrm{O}_{3}\left(\mathrm{k}(2\right.$-carene $)=2.4 \times 10^{-16}$ and $\mathrm{k}(3$-carene $)=3.7 \times 10^{-17}$, in units of $\mathrm{cm}^{3}$ molecule $\mathrm{s}^{-1}$, 
this work) are estimated to be in the range of few minutes to few hours. Ozone reactions might be important during day and night while $\mathrm{OH}$ and $\mathrm{NO}_{3}$ reactions may be of importance during the daytime and nighttime, respectively. The very short atmospheric lifetimes indicate that 2- and 3carene will be oxidized near their emission sources to form other atmospheric organic components and radicals.

The initial ozone attack on 2- and 3-carene gives an energy-rich primary ozonide (POZ), which promptly decomposes to two excited carbonyl substituted Criegee intermediates (CIs). Syn-and disubstituted CIs mainly decompose to form $\mathrm{OH}$ radicals through vinyl hydroperoxide channel in conjunction with a number of $\beta$-oxo alkyl radicals. The $\mathrm{OH}$ yields for reaction of ozone with 2and 3-carene were reported to be $0.81 \pm 0.11$ and $0.86 \pm 0.11$ respectively [22]. The high $\mathrm{OH}$ yields can be rationalized by the existence of $\beta$-vinyl hydrogen. The further chemistry of the $\beta$ oxo alkyl radicals originated from ozonolysis of 3-carene may form a number of reported multifunctional organic products containing hydroxyl, carbonyl and acid functionalities and also acetone and formaldehyde ([10] and cited refs.). Anti-conformer of CIs cannot isomerize to synconformer owing to the high energy barrier (over $20 \mathrm{kcal} \mathrm{mol}^{-1}$ [5]) and predominantly react with $\mathrm{H}_{2} \mathrm{O}$ under atmospheric conditions, leading to formation of caronaldehyde and $\mathrm{H}_{2} \mathrm{O}_{2}$, or carononic acid. Some support for this comes from the significant yield of $\mathrm{H}_{2} \mathrm{O}_{2}$ for ozonolysis of 2-carene performed close to $100 \% \mathrm{RH}$ [23] and increasing yield of 3-caronaldehyde for ozonolysis of 3-carene with increasing humidity [24]. Additionally, secondary ozonide has been observed for ozonolysis of 3-carene [25].

\section{Acknowledgments}


Labex Voltaire (ANR-10-LABX-100-01), Region Centre (France) through Formul'Air project, ANR (13-BS06-0002-01, COGNAC) and the EU-Eurochamp-2 (E2-2013-02-27-0086) projects for support. 


\section{REFERENCES}

[1] A. Guenther, C.N. Hewitt, D. Erickson, R. Fall, C. Geron, T. Graedel, P. Harley, L. Klinger, M. Lerdau, W.A. McKay, T. Pierce, B. Scholes, R. Steinbrecher, R. Tallamraju, J. Taylor, P. Zimmerman, J. Geophys. Res.: Atmos. 100 (1995) 8873.

[2] A. Guenther, ISRN Atmos. Sci. 2013 (2013) 27.

[3] D. Stone, L.K. Whalley, D.E. Heard, Chem. Soc. Rev. 41 (2012) 6348.

[4] S.S. Brown, J. Stutz, Chem. Soc. Rev. 41 (2012) 6405.

[5] D. Johnson, G. Marston, Chem. Soc. Rev. 37 (2008) 699.

[6] P.J. Ziemann, R. Atkinson, Chem. Soc. Rev. 41 (2012) 6582.

[7] M.R. McGillen, T.J. Carey, A.T. Archibald, J.C. Wenger, D.E. Shallcross, C.J. Percival, Phys. Chem. Chem. Phys. 10 (2008) 1757.

[8] F. Bernard, V. Daële, A. Mellouki, H. Sidebottom, J. Phys. Chem. A 116 (2012) 6113.

[9] F. Bernard, I. Fedioun, F. Peyroux, A. Quilgars, V. Daële, A. Mellouki, J. Aerosol Sci. 43 (2012) 14.

[10] IUPAC, Task Group on Atmospheric Chemical Kinetic Data Evaluation, http://iupac.pole-ether.fr (2013).

[11] W.J. Massman, Atmos. Environ. 32 (1998) 1111.

[12] M. Müller, T. Mikoviny, W. Jud, B. D'Anna, A. Wisthaler, Chemom. Intell. Lab. Syst. 127 (2013) 158

[13] J.G. Calvert, R. Atkinson, J. A. Kerr, Sasha Madronich, G. K. Moortgat, Timothy J. Wallington, G. Yarwood, The Mechanisms of Atmospheric Oxidation of the Alkenes, Oxford University Press, 2000.

[14] R. Atkinson, J. Arey, Chem. Rev. (Washington, DC, U. S.) 103 (2003) 4605.

[15] J. Treacy, M. Curley, J. Wenger, H. Sidebottom, J. Chem. Soc., Faraday Trans. 93 (1997) 2877.

[16] C.R. Greene, R. Atkinson, Int. J. Chem. Kinet. 24 (1992) 803.

[17] R. Atkinson, D. Hasegawa, S.M. Aschmann, Int. J. Chem. Kinet. 22 (1990) 871.

[18] E.P. Grimsrud, H.H. Westberg, R.A. Rasmussen, Int. J. Chem. Kinet. 1 (1975) 183.

[19] M. Witter, T. Berndt, O. Boge, F. Stratmann, J. Heintzenberg, Int. J. Chem. Kinet. 34 (2002) 394. 
[20] M. Duncianu, R.I. Olariu, V. Riffault, N. Visez, A. Tomas, P. Coddeville, J. Phys. Chem. A 116 (2012) 6169.

[21] D.J. Stewart, S.H. Almabrok, J.P. Lockhart, O.M. Mohamed, D.R. Nutt, C. Pfrang, G. Marston, Atmos. Environ. 70 (2013) 227.

[22] S.M. Aschmann, J. Arey, R. Atkinson, Atmos. Environ. 36 (2002) 4347.

[23] C.N. Hewitt, G. Kok, J. Atmos. Chem. 12 (1991) 181.

[24] Y. Ma, R.A. Porter, D. Chappell, A.T. Russell, G. Marston, Phys. Chem. Chem. Phys. 11 (2009) 4184.

[25] A. Vibenholt, A.W. Nørgaard, P.A. Clausen, P. Wolkoff, Chemosphere 76 (2009) 572. 


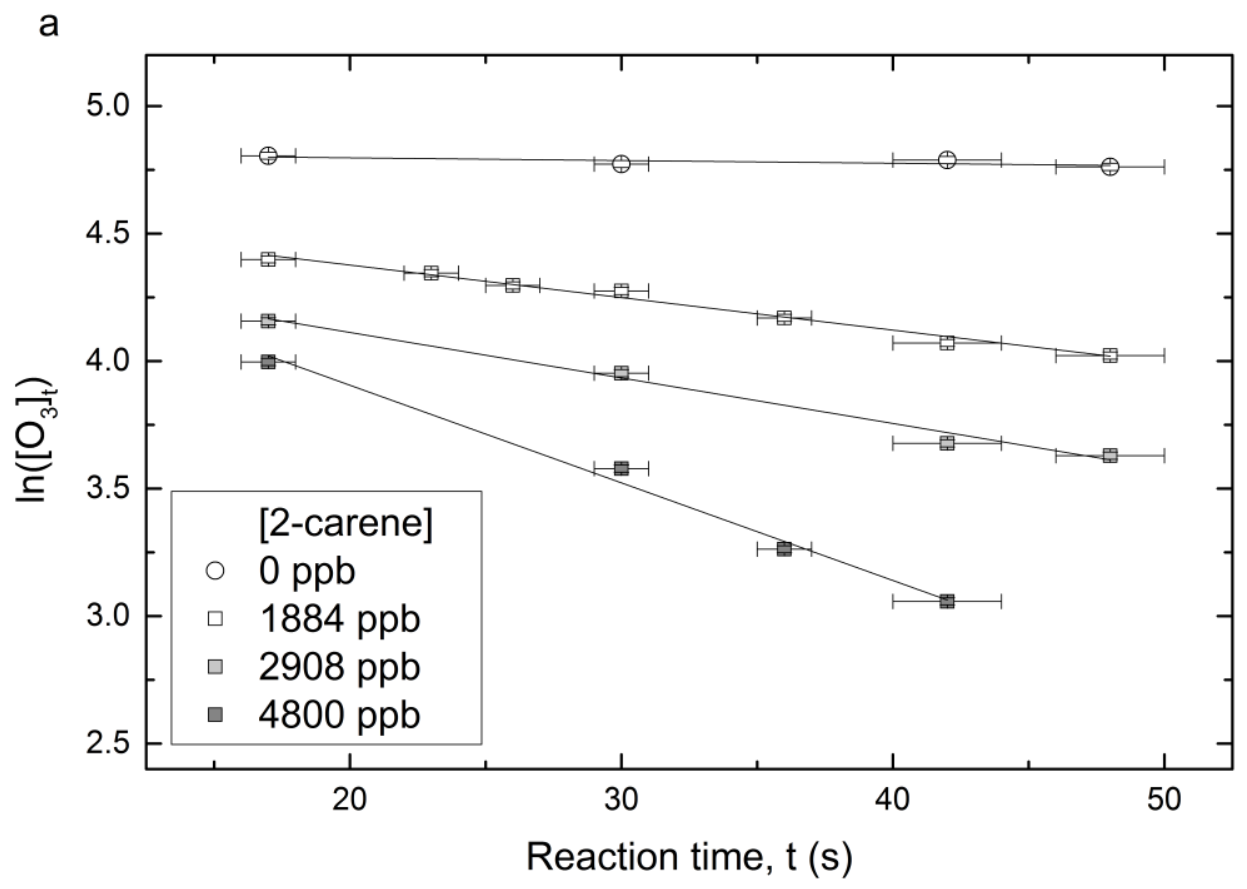

b

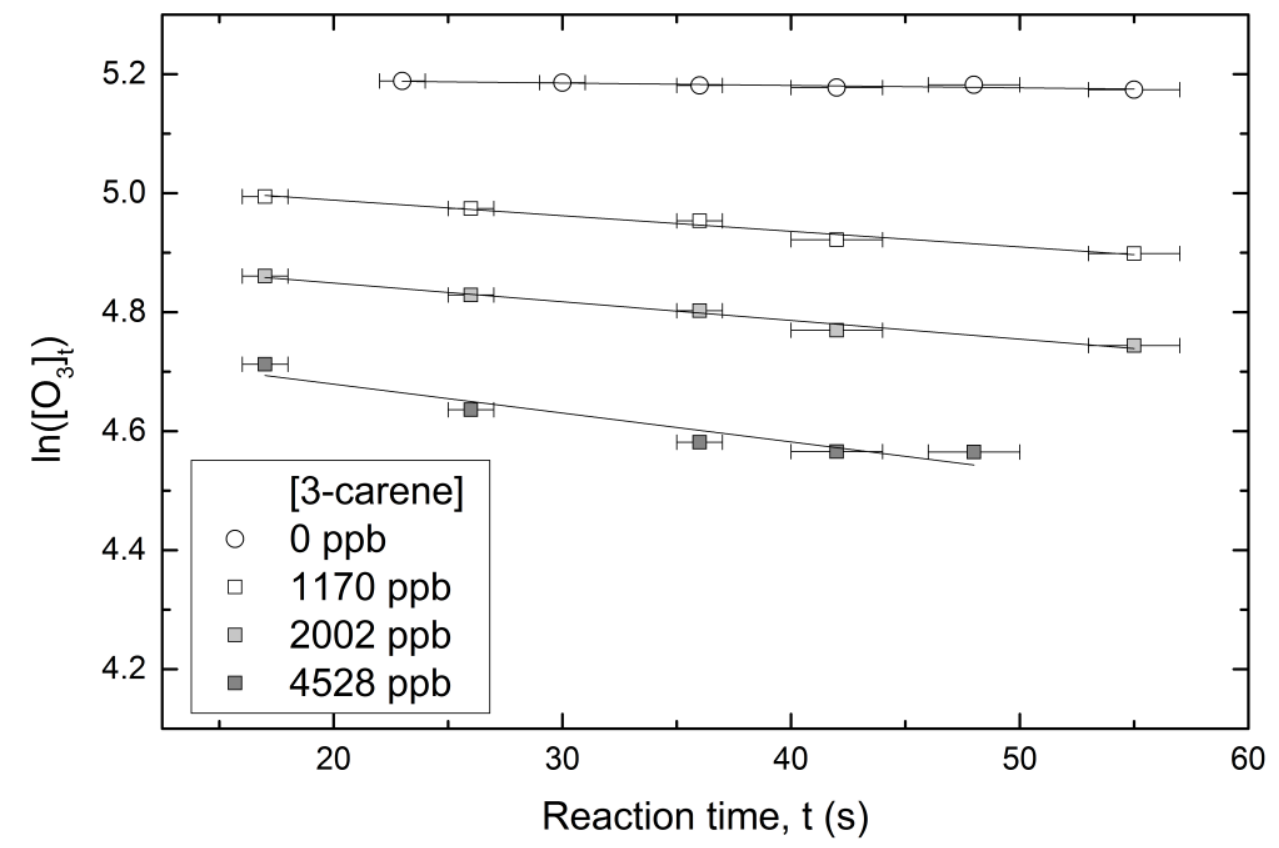

Figure 1: Reaction of ozone with (a) 2-carene and (b) 3-carene: examples of pseudo-first order plots at $296 \pm 2 \mathrm{~K}$ and $293 \pm 2 \mathrm{~K}$ obtained from experiments in the flow reactor. 

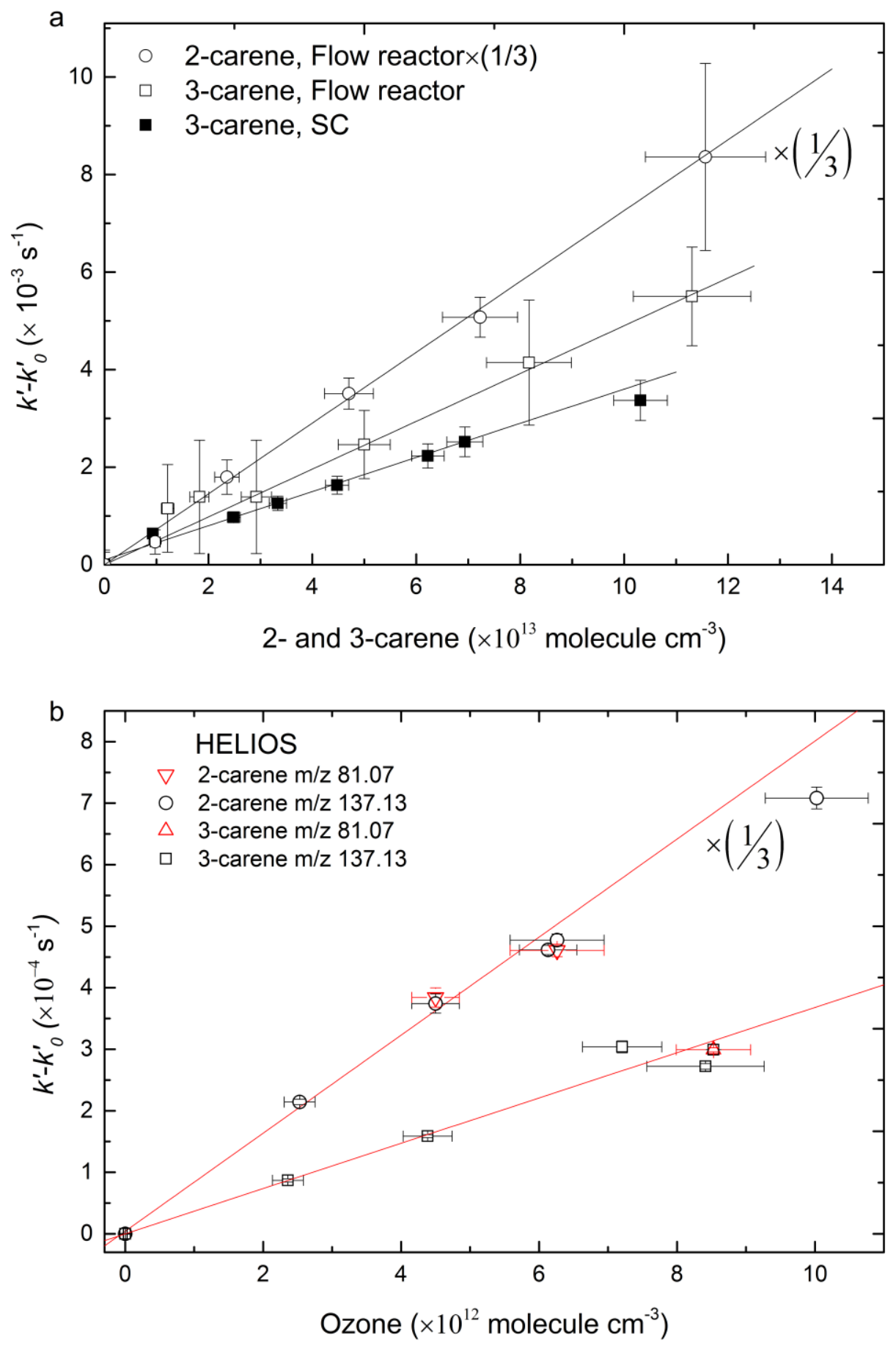

Figure 2: Pseudo-first order constants as function of concentration of carene (a) from flow reactor and SC or ozone (b) from HELIOS. The pseudo-first order constants for 2-carene timed $1 / 3$ for clearness. 


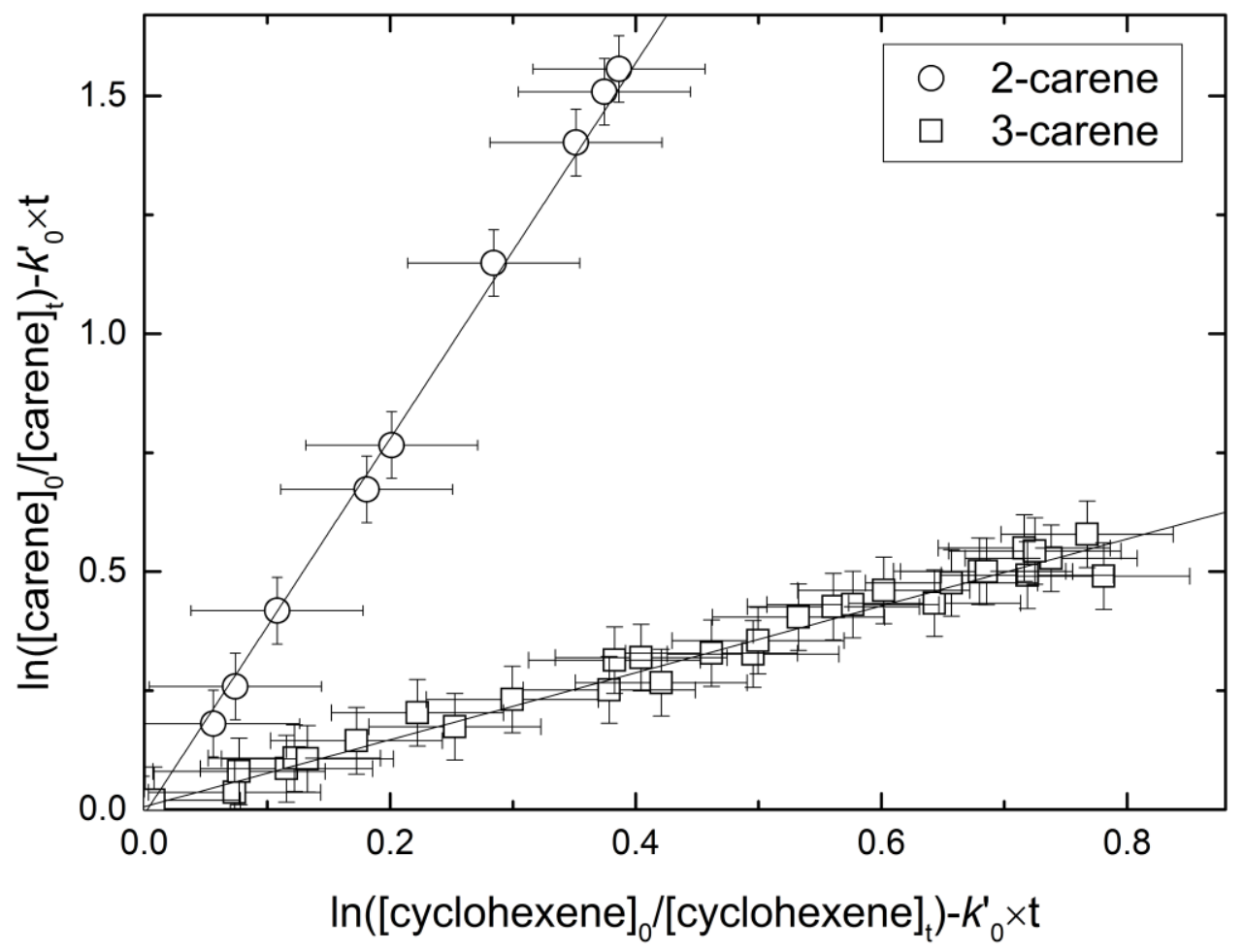

Figure 3: The decay rates of 2-carene (circle) and 3-carene (square) relative to that of cyclohexene in the presence of ozone and excess of 2-butanol. 
Table 1: Initial conditions and results obtained from the absolute measurements of rate coefficients for the recations of ozone with 2- and 3-carene at $295 \pm 3 \mathrm{~K}$ and $760 \pm 1$ torr in the flow reactor and in SC.

\begin{tabular}{|c|c|c|c|}
\hline & $\mathrm{T}(\mathrm{K})$ & $\begin{array}{c}\text { [carene] } \\
\left(\times 10^{13} \text { molecule } \mathrm{cm}^{-3}\right)\end{array}$ & $k^{\prime} \pm 1 \sigma\left(\times 10^{-2} \mathrm{~s}^{-1}\right)$ \\
\hline \multirow[t]{6}{*}{ 2-carene } & 296 & 1.0 & $0.16 \pm 0.08$ \\
\hline & 295 & 2.4 & $0.60 \pm 0.12$ \\
\hline & 295 & 4.7 & $1.17 \pm 0.11$ \\
\hline & 297 & 7.2 & $1.69 \pm 0.14$ \\
\hline & 297 & 11.6 & $2.79 \pm 0.64$ \\
\hline & $296 \pm 2$ & \multicolumn{2}{|c|}{$k=(24.7 \pm 2.5) \times 10^{-17} \mathrm{~cm}^{3}$ molecule $\mathrm{s}^{-1}$ (Flow reactor) } \\
\hline \multirow[t]{15}{*}{ 3-carene } & 295 & 1.2 & $0.12 \pm 0.09$ \\
\hline & 293 & 1.8 & $0.14 \pm 0.12$ \\
\hline & 293 & 2.9 & $0.14 \pm 0.12$ \\
\hline & 294 & 5.0 & $0.25 \pm 0.07$ \\
\hline & 294 & 8.2 & $0.41 \pm 0.13$ \\
\hline & 294 & 11.3 & $0.55 \pm 0.10$ \\
\hline & $293 \pm 2$ & \multicolumn{2}{|c|}{$k=(4.9 \pm 0.8) \times 10^{-17} \mathrm{~cm}^{3}$ molecule $\mathrm{s}^{-1} \mathrm{~s}^{-1}$ (Flow reactor $)$} \\
\hline & 295 & 0.9 & $0.06 \pm 0.01$ \\
\hline & 295 & 2.5 & $0.09 \pm 0.01$ \\
\hline & 295 & 3.3 & $0.13 \pm 0.01$ \\
\hline & 295 & 4.5 & $0.16 \pm 0.01$ \\
\hline & 295 & 6.2 & $0.22 \pm 0.01$ \\
\hline & 295 & 6.9 & $0.25 \pm 0.01$ \\
\hline & 295 & 10.3 & $0.34 \pm 0.01$ \\
\hline & $295 \pm 1$ & \multicolumn{2}{|c|}{$k=(3.5 \pm 0.2) \times 10^{-17} \mathrm{~cm}^{3}$ molecule $\mathrm{s}^{-1}(\mathrm{SC})$} \\
\hline
\end{tabular}


Table 2: Reaction of ozone with 2- and 3-carene, initial experimental conditions and pseudo-first order rate coefficients obtained in HELIOS.

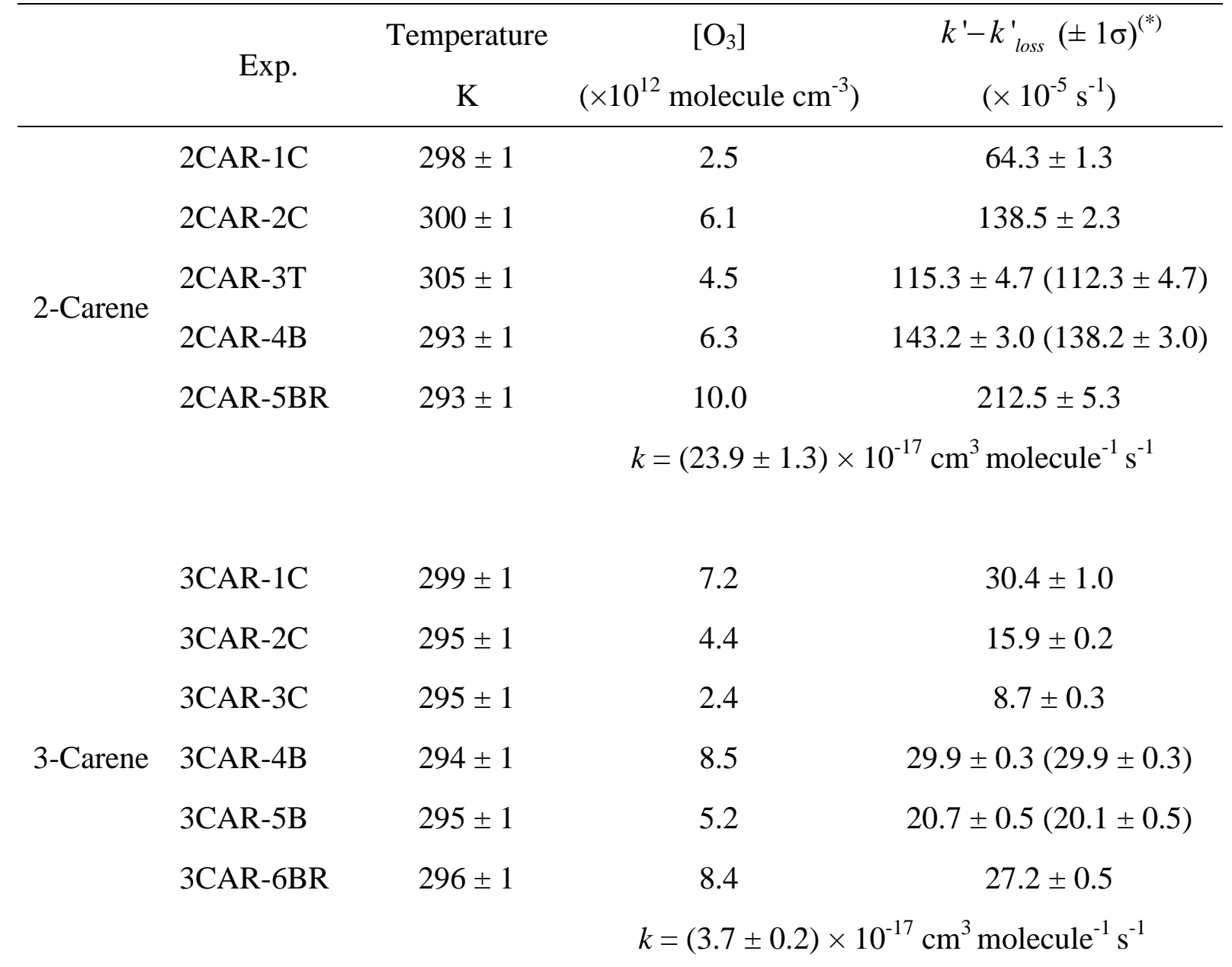

(*) Decay rate derived from $\mathrm{m} / \mathrm{z} 81$ are shown in brackets. 
Table 3: Summary of the experimental conditions and the results from the relative rate study of reaction of ozone with 2- and 3-carene in the presence of an excess of 2-butanol.

\begin{tabular}{|c|c|c|c|c|c|}
\hline Exp. & $\begin{array}{l}\text { [carene] } \\
\left(\times 10^{11}\right)^{(\mathrm{a})}\end{array}$ & $\begin{array}{l}\text { [cyclohexene] } \\
\left(\times 10^{11}\right)^{(\mathrm{a})}\end{array}$ & $\begin{array}{c}{[2 \text {-butanol] }} \\
\left(\times 10^{13}\right)^{(\mathrm{a})}\end{array}$ & $\frac{k_{\text {scav }}^{\prime}(\mathrm{b})}{k_{\text {reac }}^{\prime}}$ & $k_{i} / k_{\text {ref }}$ \\
\hline \multicolumn{6}{|c|}{$\underline{\text { 2-carene }}$} \\
\hline \multirow[t]{4}{*}{ 2CAR-SC } & 180 & 430 & 890 & 19 & $3.03 \pm 0.21$ \\
\hline & 230 & 930 & 890 & 10 & $3.34 \pm 0.57$ \\
\hline & & & & Average & $3.06 \pm 0.27$ \\
\hline & \multicolumn{5}{|c|}{$k=(24.2 \pm 2.2) \times 10^{-17} \mathrm{~cm}^{3}$ molecule $\mathrm{e}^{-1} \mathrm{~s}^{-1(\mathrm{~d})}$} \\
\hline \multirow[t]{3}{*}{ 2CAR-5BR } & 1.6 & 7.2 & 10 & 14 & $2.83 \pm 1.4$ \\
\hline & \multicolumn{5}{|c|}{$k=(22.4 \pm 1.4) \times 10^{-17} \mathrm{~cm}^{3}$ molecule $\mathrm{e}^{-1} \mathrm{~s}^{-1(\mathrm{a})}$} \\
\hline & \multicolumn{4}{|c|}{ 3-carene } & \\
\hline 3CAR-6BR & 2.4 & 7.2 & 10 & 12 & $0.44 \pm 0.01$ \\
\hline \multirow[t]{3}{*}{ 3CAR-7BR } & 7.1 & 7.2 & 16 & 12 & $0.52 \pm 0.09$ \\
\hline & & & & Average & $0.48 \pm 0.04$ \\
\hline & \multicolumn{5}{|c|}{$k=(3.8 \pm 0.3) \times 10^{-17} \mathrm{~cm}^{3}$ molecule $^{-1} \mathrm{~s}^{-1}$ (a) } \\
\hline
\end{tabular}

(a) (in units of molecule $\mathrm{cm}^{-3}$ ).

(b) $\frac{k_{\text {scav }}^{\prime}}{k_{\text {reac }}^{\prime}}=\frac{k_{O H, 1}[2-\mathrm{Butanol}]_{0}}{k_{O H, 2}[\text { carene }]_{0} \times k_{O H, 3}[\mathrm{cyclohexene}]_{0}}$, where $k(\mathrm{OH}+2$-butanol $)=8.7 \times 10^{-12} \mathrm{~cm}^{3}$ molecule $\mathrm{s}^{-1}$ [10], $k(\mathrm{OH}+2$-carene $)=8.0 \times 10^{-11} \mathrm{~cm}^{3}$ molecule $\mathrm{s}^{-1}$ [13], $k(\mathrm{OH}+3$-carene $)=$ $8.8 \times 10^{-11} \mathrm{~cm}^{3}$ molecule $\mathrm{s}^{-1}$ [13], $k(\mathrm{OH}+$ cyclohexene $)=6.77 \times 10^{-11} \mathrm{~cm}^{3}$ molecule $\mathrm{s}^{-1} \mathrm{~s}^{-1}$ [13] .

(c) Excessive concentration of 2-butanol completely consumed primary ions and thereby caused non-linear responses of carene and cyclohexene so that the obtained $k_{i} / k_{\text {ref }}$ was not included for the average.

(d) Placed on an absolute basis using $k\left(\mathrm{O}_{3}+\right.$ cyclohexene $)=7.9 \times 10^{-17} \mathrm{~cm}^{3}$ molecule $^{-1} \mathrm{~s}^{-1}$ [14]. 
Table 4: Pseudo first order rate coefficients for reaction of ozone with cyclohexene and obtained rate coefficient in comparison with literatures.

\begin{tabular}{|c|c|c|}
\hline & $\begin{array}{c}{\left[\mathrm{O}_{3}\right]} \\
\left(\times 10^{11} \text { molecule } \mathrm{cm}^{-3}\right)\end{array}$ & $\begin{array}{c}k^{\prime}-k_{\text {loss }}^{\prime}( \pm 1 \sigma) \\
\left(\times 10^{-4} \mathrm{~s}^{-1}\right)\end{array}$ \\
\hline 3CAR-6BR & 8.4 & $6.5 \pm 0.1$ \\
\hline \multirow[t]{5}{*}{ 2CAR-5BR } & 10.0 & $7.3 \pm 0.2$ \\
\hline & $k_{295 \mathrm{~K}}=(7.4 \pm 0.5) \times 10^{-17 \text { (a) }}$ & (This study) \\
\hline & $k_{295 \mathrm{~K}}=7.9 \times 10^{-17(\mathrm{a})}$ & [14] \\
\hline & $k_{298 \mathrm{~K}}=(8.5 \pm 0.8) \times 10^{-17 \text { (a) }}$ & {$[15]$} \\
\hline & $k_{295 \mathrm{~K}}=(7.05 \pm 0.11) \times 10^{-17 \text { (a) }}$ & {$[16]$} \\
\hline
\end{tabular}

(a) $\mathrm{cm}^{3}$ molecule $\mathrm{s}^{-1}$. 
Table 5: Rate coefficients values obtained in this work and from the literature for the reactions of ozone with 2- and 3-carene.

\begin{tabular}{|c|c|c|c|c|}
\hline & $k_{O_{3}}{ }^{(a)}$ & $\mathrm{T}(\mathrm{K})$ & Method & Reference \\
\hline \multirow{7}{*}{ 2-carene } & $24.7 \pm 2.5$ & $296 \pm 2$ & AM-FR & This study \\
\hline & $23.9 \pm 1.3$ & $293-305$ & AM-HELIOS & This study \\
\hline & $23.2 \pm 3.0$ & $296 \pm 2$ & AM-SC & [17] \\
\hline & $24.2 \pm 2.2$ & $296 \pm 2$ & $\begin{array}{l}\text { RM-SC, Scav. = 2-butanol, } \\
\text { Ref. = cyclohexene } \\
\text { (b) }\end{array}$ & This study \\
\hline & $22.4 \pm 1.4^{(\mathrm{f})}$ & $293 \pm 1$ & 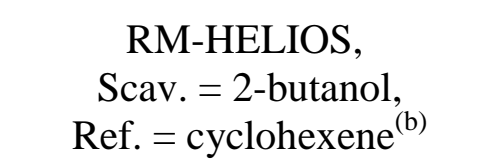 & This study \\
\hline & $25.2 \pm 2.7$ & $296 \pm 2$ & $\begin{array}{c}\text { RM, Scav. = cyclohexane } \\
\text { Ref. }=\alpha \text {-pinene }{ }^{(\mathrm{c})}\end{array}$ & {$[17]$} \\
\hline & $24 \pm 14$ & 298 & & {$[10]$} \\
\hline \multirow{9}{*}{ 3-carene } & $4.9 \pm 0.8$ & $293 \pm 2$ & AM-FR & This study \\
\hline & $3.5 \pm 0.2$ & $295 \pm 1$ & AM-SC & This study \\
\hline & $3.7 \pm 0.2$ & $296 \pm 3$ & AM-HELIOS & This study \\
\hline & 12 & $295 \pm 1$ & AM-FR & {$[18]$} \\
\hline & $5.20 \pm 0.56$ & $296 \pm 2$ & AM-SC & [17] \\
\hline & $3.8 \pm 0.3$ & $296 \pm 2$ & $\begin{array}{c}\text { RM-HELIOS, } \\
\text { Scav. = 2-butanol, } \\
\text { Ref. = cyclohexene }^{(b)}\end{array}$ & This study \\
\hline & $4.05 \pm 0.43$ & $296 \pm 2$ & $\begin{array}{c}\text { RM, Scav. = cyclohexane, } \\
\text { Ref. }=\alpha \text {-pinene }{ }^{(\mathrm{c})}\end{array}$ & {$[17]$} \\
\hline & $5.60 \pm 0.95$ & $295 \pm 0.5$ & $\begin{array}{c}\text { RM, Scav. = m-xylene, } \\
\text { Ref. = 2-methylbut-2-ene }\end{array}$ & [19] \\
\hline & $4.8 \pm 2.9$ & 298 & & {$[10]$} \\
\hline
\end{tabular}

$\mathrm{AM}=$ Absolute rate; $\mathrm{RM}=$ Relative rate; $\mathrm{FR}=$ Flow Reactor; $\mathrm{SC}=$ Simulation Chamber.

(a) $\left(\times 10^{-17} \mathrm{~cm}^{3}\right.$ molecule $\left.\mathrm{s}^{-1}\right)$

(b) Placed on an absolute basis using $k\left(\mathrm{O}_{3}+\right.$ cyclohexene $)=7.9 \times 10^{-17} \mathrm{~cm}^{3}$ molecule $\mathrm{s}^{-1} \mathrm{~s}^{-1}[14]$.

(c) Placed on an absolute basis using $k\left(\mathrm{O}_{3}+\alpha\right.$-pinene $)=9.3 \times 10^{-17} \mathrm{~cm}^{3}$ molecule $\mathrm{s}^{-1}[10]$.

(d) Placed on an absolute basis using $k\left(\mathrm{O}_{3}+2\right.$-methylbut-2-ene $)=3.92 \times 10^{-16} \mathrm{~cm}^{3}$ molecule $^{-1} \mathrm{~s}^{-1}$ [10]. 